On-Machine Acceptance

Federal Manufacturing \& Technologies

K. F. Arnold

KCP-613-6288

Published February 2000

Final Report/Project Accomplishments Summary

CRADA Number 99KCP1079

Approved for public release; distribution is unlimited.

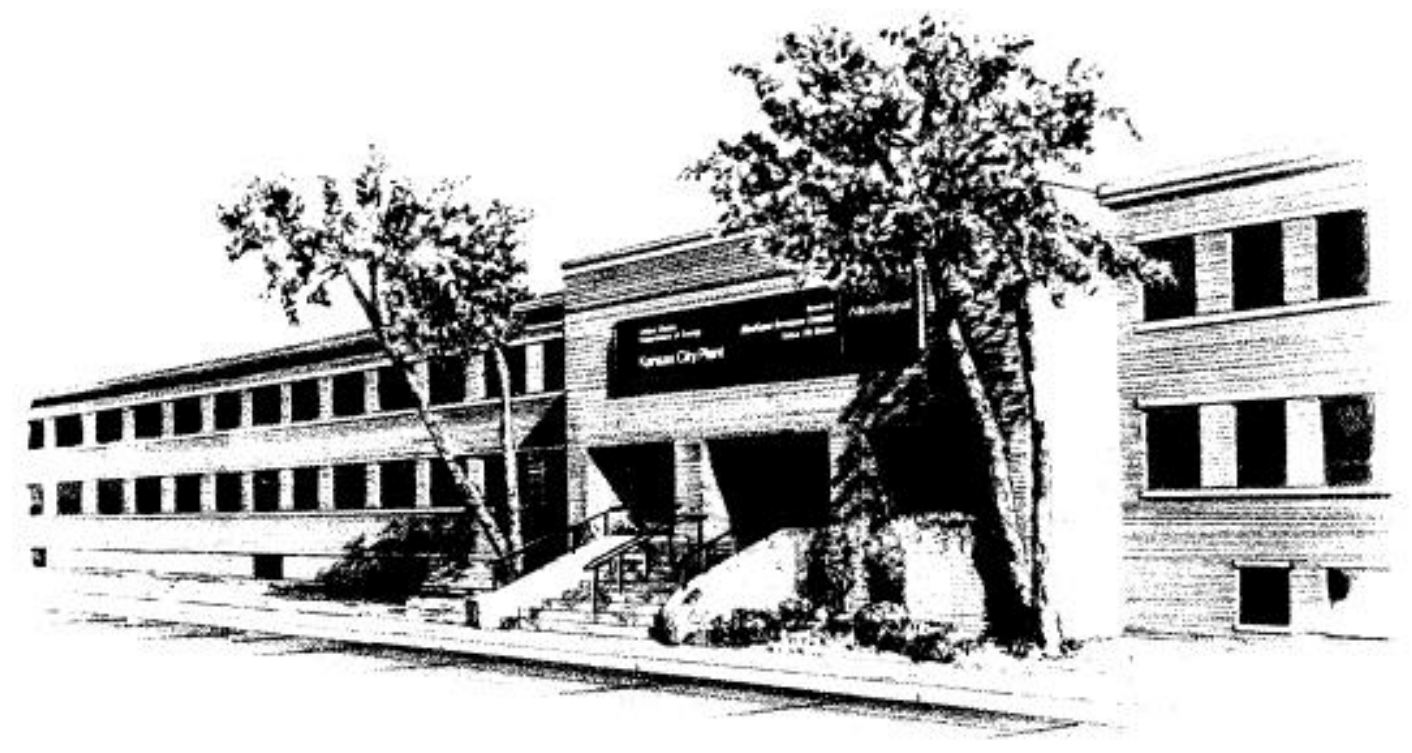

Prepared Under Contract Number DE-ACO4-76-DP00613 for the

United States Department of Energy

\title{
DISCLAIMER
}

This report was prepared as an account of work sponsored by an agency of the United States Government. Neither the United States Government nor any agency thereof, nor any of their employees, makes any warranty, express or implied, or assumes any legal liability or responsibility for the accuracy, completeness, or usefulness of any information, apparatus, product, or process disclosed, or represents 
that its use would not infringe privately owned rights. Reference herein to any specific commercial product, process, or service by trade names, trademark, manufacturer, or otherwise, does not necessarily constitute or imply its endorsement, recommendation, or favoring by the United States Government or any agency thereof. The views and opinions of authors expressed herein do not necessarily state or reflect those of the United States Government or any agency thereof.

Printed in the United States of America.

This report has been reproduced from the best available copy.

Available to DOE and DOE contractors from the Office of Scientific and Technical Information, P. O. Box 62, Oak Ridge, Tennessee 37831; prices available from (865) 576-8401, FTS 626-8401.

Available to the public from the National Technical Information Service, U. S. Department of Commerce, 5285 Port Royal Rd., Springfield, Virginia 22161, (703) 487-4650.

Honeywell

Federal Manufacturing

$\&$ Technologies

P. O. Box 419159

A prime contractor with the United States

Kansas City, Missouri

Department of Energy under Contract Number

64141-6159

DE-ACO4-76-DP00613.

KCP-613-6288

Distribution Category UC-706

Approved for public release; distribution is unlimited. 
K. F. Arnold

Published February 2000

Final Report/Project Accomplishment Summary

CRADA Number 99KCP1079

\section{On-Machine Acceptance}

Project Accomplishments Summary

CRADA Number 99KCP1079

Date: $12 / 22 / 99$

Revision: A

A. Parties

The project is a relationship between

Honeywell FM\&T

Automated Precision, Inc.

2000 E $95^{\text {th }}$ Street

7901-C Cessna Ave

PO Box 419159

Gaithersburg, MD 20879

Kansas City, MO 64141-6159

Sandia National Laboratory

MS 0958

Building 957

1515 Eubank Blvd. SE

Albuquerque, NM 87123 


\section{B. Background}

Probing processes are used intermittently and not effectively as an on-line measurement device. This project was needed to evolve machine probing from merely a setup aid to an on-the-machine inspection system. Use of probing for on-machine inspection would significantly decrease cycle time by elimination of the need for first-piece inspection (at a remote location). Federal Manufacturing \& Technologies (FM\&T) had the manufacturing facility and the ability to integrate the system into production. The Contractor had a system that could optimize the machine tool to compensate for thermal growth and related error.

C. Description

To develop a systematic application of probing on two axis machining centers for first-piece inspection of contours.

D. Expected Economic Impact

No impact due to project cancellation.

E. Benefits to DOE

No impact due to project cancellation. 


\section{F. Industry Area}

On-machine measurement

G. Project Status

Terminated due to lack of funding.

H. Point of Contact for Project Information

Ken Bauer

US Department of Energy

Kansas City Area Office

PO Box 410202

Kansas City, MO 64141-0202

Telephone: (816) 997-3917

Fax: (816) 997-5059

I. Company Size and Point of Contact

N/A

J. Project Examples

N/A

K. Technology Commercialization

N/A
Karl Arnold

Honeywell FM\&T

PO Box 419159

Kansas City, MO 64141-6159

Telephone: (816) 997-4819

Fax: (816) 997-4298 


\section{Release of Information}

I have reviewed the attached Project Accomplishment Summary prepared by Honeywell FM\&T and agree that the information about our CRADA may be released for external distribution.

Original signed by $2 / 4 / 00$

Name: Kam Lau

Date

Organization: President

Title: Automated Precision, Inc. 